\title{
BARRIERS TO INTRODUCTION OF SMOKE-FREE WORKPLACES IN CENTRAL EUROPE: EXAMPLE OF THE CZECH REPUBLIC
}

\author{
Eva Králíkovái, ${ }^{2}$, Alexandra Pánková1,2 \\ ${ }^{1}$ Institute of Hygiene and Epidemiology, First Faculty of Medicine, Charles University and General University Hospital in Prague, Prague, \\ Czech Republic \\ ${ }^{2}$ Centre for Tobacco Dependence, Third Medical Department, Department of Endocrinology and Metabolism, First Faculty of Medicine, \\ Charles University and General University Hospital in Prague, Prague, Czech Republic
}

\section{SUMMARY}

Objectives: Smoking at the workplace has a negative impact both on employers' economic interests and employees' health. The aim of this study is to describe the current situation, mainly barriers in implementation and resources in the Czech Republic as an example of a Central European country.

Methods: We synthesised relevant review papers with our knowledge of the local situation based upon professional experience of both authors.

Results: Despite smoke-free laws, some EU workers are still exposed to passive smoking during working hours. The main barriers towards smoke-free workplace implementation are the lack of resources, perception of smoking as a norm, and exceptions for leading personalities and their smoking. Social support increases smoking cessation effectiveness. Low availability of local smoking cessation services is an overall problem in Central Europe.

Conclusions: The working environment influences smoking habits. Smoking cessation support is cost-effective not only for the smoking employee but for employers as well. Smoking cessation resources should be available during the working day. No exceptions should be made as they serve as barriers to a smoke-free working environment.

Key words: smoking, employers, employees, economic, health, smoking cessation

Address for correspondence: E. Králíková, Institute of Hygiene and Epidemiology, First Faculty of Medicine, Charles University, Studničkova 7 , 12800 Prague 2, Czech Republic. E-mail: eva.kralikova@lf1.cuni.cz

https://doi.org/10.21101/cejph.a6160

\section{INTRODUCTION}

Smoking seriously affects not only the health of active and passive smokers, but also has a large economic impact for both employees and employers $(1,2)$. Despite the fact that the EU has smoke-free laws, a substantial proportion of people are still exposed to passive smoking at the workplace (3). In the Czech Republic, where a smokefree law was introduced on 31 May 2017 (4), 17\% of smokers versus $12 \%$ of non-smokers were exposed to second-hand smoke (SHS) at the workplace during that year, with men almost twice as much exposed as women (5).

Health effects of long-term exposure to SHS can be well illustrated using mortality and morbidity changes after the implementation of smoke-free laws, when the SHS exposure is reduced. The Irish smoke-free law was introduced in 2004 and thus Ireland became the first country globally with all indoor public spaces smoke-free. It was followed by a $13 \%$ decrease in early all-cause mortality $26 \%$ reduction in ischaemic heart disease (IHD), $32 \%$ reduction in stroke and $38 \%$ reduction in chronic obstructive pulmonary disease mortality (COPD). Post-ban risk differences did not change with a longer follow-up period. Mortality decreases were primarily due to reduced exposure to SHS (6). Furthermore, a significant reduction in small-for-gestational birth rates both immediately and sustained over the post-ban period were recorded in Ireland (7). Important factors in Ireland's pioneering action included a committed health minister backed by the entire Cabinet, and active support from labour unions representing hospitality industry workers, for whom indoor spaces such as bars are their workplaces. A German study by Fischer and Kraemer, where a software tool applying a Markov model for health impact assessment was used, estimated that overall 687,254 IHD cases, 231,973 COPD cases and 288,015 stroke cases yearly were attributable to SHS exposure in Germany in 2014 (8). SHS exposure at work is associated with increased COPD risk (9) and thus may be considered as a risk factor of occupational COPD. There was a positive court decision in the EU attributing a significant proportion of cancer disease to the SHS exposure of the employee, even though the worker was a smoker (10).

\section{MATERIALS AND METHODS}

Description of the current situation regarding smoke-free workplaces in the Czech Republic could serve as an example of problems with implementation typical for Central European 
countries. Based on many review articles on this topic already available, we synthesise our experience with local conditions and point out barriers towards the implementation of smokefree workplaces.

\section{RESULTS}

\section{Smoke-free Workplaces: Barriers for Implementation}

Basically all EU countries are covered by smoke-free laws, if not $100 \%$, with very few exceptions which are hard to fulfil - e.g. in the Czech Republic, according to the act No. $67 / 2017$ (4), all indoor public spaces are declared smoke-free: an exception is that smoking is allowed in restaurants in a room with a separate outside entrance with no service - but that is difficult to realize. Before such laws were adopted, some businesses introduced voluntary smoke-free policies in response to popular demand (11).

The first step should be mapping smoking habits among employees, and long-term preparation of a smoking ban (10). This is demonstrated in a case study of a large steel industry facility in Ostrava, ArcelorMittal, with approximately 7,500 employees. On 1 September 2015, the company went completely smoke-free. It happened after five years of step-by-step explanation, information, gradual restrictions of smoking possibilities, and smoking cessation support (specialist intervention and covering costs of medication). The smoking ban was respected also by visitors and truck drivers (12). Hopefully, the policy will continue.

As for overall health support at the workplace, barriers can include a competitive business environment, reorganizations, lack of resources (financial, personal, material), and inappropriate interventions. In a small organization $(<500$ employees) it is challenging to assemble a critical mass of potential participants to take part in the intervention; in a large one, numerous competing priorities may be a barrier, or the existence of different company locations (13). A smoke-free workplace offers overall benefits, but some possible problems must also be considered, such as the concentration of smokers outside buildings, or more intensive smoking before and after working shifts (14). But, overall, there are no adverse effects of smoke-free workplace policies (15).

Based on our local knowledge, smoking areas should be carefully selected (places that are unsuitable or hard to reach or that disturb the local neighbourhood must be avoided).

\section{Economic Impact of Smoking for Employers}

The impact for the smoker is well known but less is known about that for the employer. Apart from costs such as fire damage, cleaning and ventilation, and lower work productivity (10), smoking employees mean a cost of lost working time. Even if the indoor workplace is declared as smoke-free, those who continue to smoke have to go outside to have their cigarettes. This means typically about 15 minutes per employee spent because of one cigarette. If a smoker smokes e.g. four cigarettes per working day, and if the smoking prevalence is at least $25 \%$ in Europe (24\% of daily smokers) (16), the employer can easily count working hours lost due to smoking. E.g. in case of 1,000 employees, about 250 may be smokers, losing 250 hours daily, $250 \times 5=1,250$ hours weekly, or $1,250 \times 52=65,000$ hours yearly. The total of unproductive salary costs can be calculated. Smokers also have more sick days compared to non-smokers: between 3 to 7 more days per year $(17,18)$. This corresponds with the proven fact that the main cost of smoking to a nation's economy is the loss of productive working life.

\section{Social Support}

The social environment influences smoking habits, both in the general population and in smaller communities. Since we spend substantial time at work, the social environment is important in this sense, both in keeping it smoke-free and in successful quitting. Also, population subgroups should be considered (19). Of great importance is the attitude of leading personalities including their personal example. The effectiveness of smoking cessation incentives and competitions is uncertain (20).

\section{Demands and Stress}

Working demands may play both positive and negative roles in smoking cessation. They can stimulate people to stop smoking (personal image, bad smell, high demands, no time or possibility to smoke), but if the demands and stress are too high, they may lead to relapse $(21,22)$.

\section{Resources for Smoking Cessation}

Treatment of tobacco dependence should be available within existing healthcare systems, as the World Health Organization recommends in its Framework Convention on Tobacco Control, Article 14 (23). Unfortunately, there is a lack of such services in the Eastern part of Europe $(3,24)$. But still, employers could start cooperation with local physicians or specialists trained in smoking cessation. The list of trained medical doctors can be easily found at the webpage of the Society for Treatment of Tobacco Dependence*.

In some professions, high smoking prevalence, e.g., nurses or doctors and other professions across the health system, may be a barrier, as smokers cannot be credible counsellors (25-27). Among Czech nurses, about 40\% smoke $(24,26,27)$.

\section{Smoking Prevalence in the Population}

In restaurants, the smoke-free law mostly works - during 2018 in Prague there were 632 controls in restaurants, dining rooms, bars, pubs, and other catering businesses with only 48 faults - not only because of smoking, but also due to missing/ wrongly placed signs "Smoking is not permitted on these premises", inappropriate placement of signs prohibiting the sale of alcoholic drinks and tobacco products to those younger than 18 years, or breach of the obligation of food service operators to alert a person who does not comply with the smoking ban to stop smoking or leave the area. For these 48 faults, total fines of 82,000 CZK were imposed (28).

However, more likely other workplaces may be a problem. The authors have personal experience from hospitals, where both

* https://www.slzt.cz 
the staff and patients smoke in toilets despite the smoke-free law. These cases were rather random and there were attempts to solve them by personal discussion. Also in large, old facilities there might be some spaces difficult to control.

\section{DISCUSSION}

There are over 500 reviews about smoke-free workplaces available on PubMed, but only a few provide information about the real situation and barriers to implementation. The costs to employers of providing smoking-cessation pharmacotherapy to their employees is low and it may reduce the proportion of employees who smoke (29).

Employers should take social responsibility to support smoking cessation. There should be more robust leadership at the state level, as well as through advocacy, public health, and clinician organizations; there is little support from government, insufficient smoking cessation services, and incomplete reimbursement of pharmaceutical costs in Central Europe, especially in the Eastern part $(30,31)$.

The level of tobacco control, including laws and their application, depends on the level of political corruption in the given country - and this applies to compliance with legislation overall (32). Also, personal examples of leading politicians in the country as well as enterprise and company headquarters play important role.

\section{CONCLUSIONS}

Smoke-free workplace and smoking cessation support from the employer should be a standard part of the mosaic of tobacco control in the population. Employers should be concerned about smoking by their employees not limited to the working hours, but motivate them to stop smoking, support their treatment and consider the reality of conditions for $100 \%$ implementing smoke-free workplaces.

\section{Acknowledgement}

This paper was supported by the Charles University project PROGRES Q25/LF1.

\section{Conflict of Interests}

None declared

\section{REFERENCES}

1. Hahn EJ. Smokefree legislation: a review of health and economic outcomes research. Am J Prev Med. 2010;39(6 Suppl 1):S66-76.

2. Hopkins DP, Razi S, Leeks KD, Kalra GP, Chattopadhyay SK, Soler $\mathrm{RE}$, et al. Smokefree policies to reduce tobacco use: a systematic review. Am J Prev Med. 2010;38(Suppl 2):S275-89.

3. Olivieri M, Murgia N, Carsin AE, Heinrich J, Benke G, Bono R, et al. Effects of smoking bans on passive smoking exposure at work and at home. The European Community respiratory health survey. Indoor Air. 2019;29(4):670-9.

4. Act No. 65 on health protection against harmful effects of addictive substances of January 19, 2017. Sbírka zákonů ČR. 2017 Mar 3; Pt 21:671-99. (In Czech.)
5. Csémy L, Dvořáková Z, Fialová A, Kodl M, Skývová M. Use of tobacco and alcohol in the Czech Republic in 2018 [Internet]. Prague: NIPH; 2018 [cited 2020 Jul 19]. Available from: http:/www.szu.cz/ uploads/documents/szu/aktual/uzivani_tabaku_alkoholu_cr_2018.pdf. (In Czech.)

6. Stallings-Smith S, Zeka A, Goodman P, Kabir Z, Clancy L. Reductions in cardiovascular, cerebrovascular, and respiratory mortality following the national Irish smoking ban: interrupted time-series analysis. PLoS One. 2013;8(4):e62063. doi: 10.1371/journal.pone.0062063.

7. Kabir Z, Daly S, Clarke V, Keogan S, Clancy L. Smoking ban and small-for-gestational age births in Ireland. PLoS One. 2013;8(3):e57441. doi: 10.1371/journal.pone.0057441.

8. Fischer F, Kraemer A. Health impact assessment for second-hand smoke exposure in Germany-quantifying estimates for ischaemic heart diseases, COPD, and stroke. Int J Environ Res Public Health. 2016;13(2):198. doi: 10.3390/ijerph13020198.

9. van Koeverden I, Blanc PD, Bowler RP, Arjomandi M. Secondhand tobacco smoke and COPD risk in smokers: a COPDGene Study Cohort Subgroup Analysis. COPD. 2015;12(2):182-9.

10. European Agency for Health and Safety at Work. Tobacco: advice for employers on creating a smoke-free working environment. E-Fact 61 [Internet]. EU-OSHA; 2012 [cited July 19, 2020]. Available from: https:/osha.europa.eu/en/tools-and-publications/publications/e-facts/ efact-61-tobacco-advice-for-employers-on-creating-a-smoke-freeworking-environment/view.

11. McDaniel PA, Malone RE. Businesses' voluntary pro-health tobacco policies: a review and research agenda. Tob Control. 2012;21(1):66-72.

12. Gračková I. Manager from Arcelor Mittal describes how giant company became smoke-free. Totally. An interview [Internet]. Neovlivní. cz; 2015 [cited 2020 Jul 19]. Available from: https://neovlivni.cz/ manazer-z-arcelor-mittal-popisuje-jak-se-v-obri-firme-prestalokourit-uplne/. (In Czech.)

13. Wierenga D, Engbers LH, Van Empelen P, Duijts S, Hildebrandt VH, Van Mechelen W, et al. What is actually measured in process evaluations for worksite health promotion programs: a systematic review. BMC Public Health. 2013;13:1190. doi: 10.1186/1471-2458-13-1190.

14. Bell K, McCullough L, Devries K, Jategaonkar N, Greaves L, Richardson L, et al. Location restrictions on smoking: assessing their differential impacts and consequences in the workplace. Can J Public Health. 2009;100(1):46-50.

15. Wolfenden L, Goldman S, Stacey FG, Grady A, Kingsland M, Williams CM, et al. Strategies to improve the implementation of workplace-based policies or practices targeting tobacco, alcohol, diet, physical activity and obesity. Cochrane Database Syst Rev. 2018;2018(11):CD012439. doi: 10.1002/14651858.CD012439.pub2.

16. Attitudes of Europeans towards tobacco and electronic cigarettes. Special Eurobarometer 458 [Internet]. European Union; 2017 [cited 2002 Jul 19]. Available from: https://ec.europa.eu/commfrontoffice/ publicopinion/index.cfm/Survey/getSurveyDetail/instruments/SPECIAL/surveyKy/2146.

17. Troelstra SA, Coenen P, Boot CR, Harting J, Kunst AE, Van der Beek A, et al. Smoking and sickness absence: a systematic review and meta-analysis. Scand J Work Environ Health. 2020;46(1):5-18.

18. Lundborg P. Does smoking increase sick leave? Evidence using register data on Swedish workers. Tob Control. 2007;16(2):114-8.

19. Jepson RG, Harris FM, Platt S, Tannahill C. The effectiveness of interventions to change six health behaviours: a review of reviews. BMC Public Health. 2010;10:538. doi: 10.1186/1471-2458-10-538.

20. Leeks KD, Hopkins DP, Soler RE, Aten A, Chattopadhyay SK; Task Force on Community Preventive Services. Worksite-based incentives and competitions to reduce tobacco use: a systematic review. Am J Prev Med. 2010;38(Suppl 2):S263-74.

21. Zhou L, Niu L, Jiang H, Jiang C, Xiao S. Facilitators and barriers of smokers' compliance with smoking bans in public places: a systematic review of quantitative and qualitative literature. Int $\mathrm{J}$ Environ Res Public Health. 2016;13(12):1228.

22. Perdikaris P, Kletsiou E, Gymnopoulou E, Matziou V. The relationship between workplace, job stress and nurses' tobacco use: a review of the literature. Int J Environ Res Public Health. 2010;7(5):2362-75.

23. World Health Organization. WHO Framework Convention on Tobacco Control. Geneva: WHO; 2005.

24. Zvolská K, Králíková E. Centers for Tobacco-Dependent in the Czech Republic in 2016. Cas Lek Cesk. 2017;156(1):19-23. (In Czech.) 
25. Mujika A, Arantzamendi M, Lopez-Dicastillo O, Forbes A. Health professionals' personal behaviours hindering health promotion: a study of nurses who smoke. J Adv Nurs. 2017;73(11):2633-41.

26. Rezk-Hanna M, Sarna L, Petersen AB, Wells M, Nohavova I, Bialous $\mathrm{S}$, et al. Attitudes, barriers and facilitators to smoking cessation among Central and Eastern European nurses: a focus group study. Eur J Oncol Nurs. 2018;35:39-46.

27. Králíková E, Felbrová V, Kulovaná S, Malá K, Nohavová I, Roubíčková E, et al. Nurses' attitudes toward intervening with smokers: their knowledge, opinion and e-learning impact. Cent Eur J Public Health. 2016;24(4):272-5.

28. Shumova Z. In 2018, Prague hygienists imposed fines for 82,000 crowns as a part of the anti-smoking law [Internet]. Prague: Department of Hygiene of the Capital Town Prague; 2019 [cited 2020 Jul 19]. Available from: http://www.hygpraha.cz/dokumenty/kontroly-zakona-c--65-2017--oochrane-zdravi-pred-skodlivymi-ucinky-navykovych-latek--v-obdobi-od1--1--2018-do-31--12--2018-4145_4145_161_1.html. (In Czech.)
29. Burns ME, Rosenberg MA, Fiore MC. Use and employer costs of a pharmacotherapy smoking-cessation treatment benefit. Am J Prev Med. 2007;32(2):139-42.

30. Gollust SE, Schroeder SA, Warner KE. Helping smokers quit: understanding the barriers to utilization of smoking cessation services. Milbank Q. 2008;86(4):601-27.

31. Fraser KG, Pánková A, Zvolská K, Králíková E. FCTC implementation: the role of state or non-government organizations? An example of the Czech Republic. Cent Eur J Public Health. 2019;27(3):175-81.

32. Sy DK; Southeast Asia Tobacco Control Alliance, editors. Anticorruption and Tobacco Control [Internet]. Bangkok: SEATCA; 2017 [cited 2020 Jul 19]. Available from: https://seatca.org/dmdocuments/ Anti\%20Corruption $\% 20 \% 26 \% 20$ TC $\% 2016 \% 20$ November $\% 20 \mathrm{FI}$ NAL.pdf.

Received March 1, 2020 Accepted in revised form July 26, 2020 